\title{
Sprawozdanie
}

\section{Ogólnopolski Zjazd Katedr i Zakładów Systemów Politycznych, Gdynia, 16-17 maja 2016 r.}

W dniach 16-17 maja 2016 r. odbył się w Gdyni V Ogólnopolski Zjazd Katedr i Zakładów Systemów Politycznych. Organizatorem wydarzenia był Zakład Systemów Politycznych Instytutu Politologii Uniwersytetu Gdańskiego kierowany przez dra hab. Andrzeja Kubkę, prof. UG. Konferencja w Gdyni wpisała się w tradycję corocznych spotkań naukowych pracowników katedr i zakładów systemów politycznych z całej Polski. Tradycję tę zapoczątkował w 2012 r. Zakład Systemów Politycznych Uniwersytetu Warszawskiego, organizując w Domu Pracy Twórczej „Mądralin” pod Warszawą I Zjazd Katedr i Zakładów Systemów Politycznych i Ustrojów Państwowych. Tematem przewodnim tamtego spotkania były systemy rządów w perspektywie politologicznej. Drugi zjazd badaczy systemów politycznych został zorganizowany przez Zakład Systemów Politycznych i Administracyjnych Uniwersytetu Wrocławskiego i odbył się w Trzebnicy. Tytuł konferencji brzmiał: „System polityczny - od nowoczesnej do ponowoczesnej rzeczywistości polityki”. W kolejnych latach pracownicy katedr i zakładów systemów politycznych spotkali się w Ostromecku, na zaproszenie Katedry Systemu Politycznego RP Uniwersytetu Mikołaja Kopernika w Toruniu, oraz w Wiśle, gdzie gospodarzem spotkania był Zakład Systemów Politycznych Państw Wysoko Rozwiniętych Uniwersytetu Śląskiego. Konferencja w Ostromecku została poświęcona roli obywatela w kształtowaniu systemu politycznego, natomiast obrady IV zjazdu w Wiśle koncentrowały się wokół współczesnych badań nad partiami politycznymi. 
Zwyczaj odbywania regularnych spotkań naukowych pracowników katedr o tym samym profilu badawczym i organizowanych za każdym razem przez inny ośrodek akademicki jest szczególnie żywy w środowisku prawniczym (bodaj najdłuższą tradycję mają zjazdy konstytucjonalistów). Taka formuła dyskusji naukowej i wymiany poglądów ma ewidentne zalety. Na pierwszy plan wysuwa się oczywiście funkcja integracyjna, odgrywająca znacznie większą rolę niż w przypadku jednorazowych przedsięwzięć naukowych. Cykliczność spotkań sprzyja instytucjonalizacji kontaktów pomiędzy poszczególnymi ośrodkami akademickimi, stwarza okazję do nawiązywania współpracy pomiędzy uczonymi o podobnych zainteresowaniach naukowych, ułatwia powstawanie międzyuczelnianych zespołów badawczych i projektów naukowych o ogólnopolskim (lub przynajmniej ponadlokalnym) zasięgu. Udział w kolejnych zjazdach kształtuje poczucie przynależności do pewnej wspólnoty uczonych, wzmacnia tożsamość grupową. Ponadto powtarzalność spotkań naukowych zapewnia określoną ciągłość i wszechstronność dyskusji. Pewne wątki czy tematy, które nie zostały wyczerpane podczas jednego zjazdu mogą być kontynuowane i rozwijane na kolejnych spotkaniach. Z drugiej strony unika się powtarzania tematów, ponieważ tytuł każdej konferencji jest inny, uzgadniany przez organizatorów kolejnych zjazdów (kierowników poszczególnych katedr). Tematyka zjazdów jest w zasadzie komplementarna, co pozwala spojrzeć na systemy polityczne z różnych punktów widzenia, a w konsekwencji - całościowo.

Piąty zjazd katedr i zakładów systemów politycznych miał autentycznie ogólnopolski charakter. Konferencja w Gdyni zgromadziła ponad sześćdziesięciu uczestników z blisko dwudziestu ośrodków akademickich, co należy uznać za niewątpliwy sukces organizatorów. Wśród najliczniej reprezentowanych uczelni znalazły się: Uniwersytet Śląski, Uniwersytet Marii Curie-Skłodowskiej oraz Uniwersytet Łódzki. Na liście uczestników konferencji obecni też byli politolodzy z: Uniwersytetu Szczecińskiego, Uniwersytetu Warmińsko-Mazurskiego, Uniwersytetu Kazimierza Wielkiego, Uniwersytetu Mikołaja Kopernika, Uniwersytetu Kardynała Stefana Wyszyńskiego, Uniwersytetu Warszawskiego, Uniwersytetu Opolskiego, Uniwersytetu Rzeszowskiego, Uniwersytetu Jagiellońskiego, Uniwersytetu Wrocławskiego, Uniwersytetu Zielonogórskiego, Uniwersytetu Pedagogicznego w Krakowie, 
Akademii im. Jana Długosza w Częstochowie, Akademii Ignatianum w Krakowie oraz Koszalińskiej Wyższej Szkoły Nauk Humanistycznych.

Wzorem poprzednich spotkań organizatorzy piątego zjazdu katedr i zakładów systemów politycznych wybrali dość szeroki temat konferencji, brzmiący: „Dynamika systemów politycznych”. W zaproszeniu wystosowanym przez dyrekcję i pracowników Instytutu Politologii Uniwersytetu Gdańskiego zaproponowano, aby analizy i dyskusje koncentrowały się wokół następujących zagadnień: dialektyka stabilności i zmiany systemów politycznych, czynniki zmiany systemów politycznych, procesy przeobrażeń systemów politycznych, kierunki rozwoju współczesnych systemów politycznych, strategie analityczne w badaniach zmiany systemów politycznych.

Konferencja rozpoczęła się od powitania uczestników przez przewodniczącego Komitetu Organizacyjnego - dra hab. Andrzeja Kubkę, prof. UG. Następnie głos zabrał członek Komitetu Naukowego zjazdu, prodziekan Wydziału Nauk Społecznych UG - prof. dr hab. Bogdan Chrzanowski. O randze wydarzenia świadczył fakt obecności podczas otwarcia konferencji prezydenta Gdyni - Wojciecha Szczurka, który wygłosił do uczestników krótkie przemówienie.

Merytoryczną część konferencji zapoczątkował wykład dra hab. Jacka Wojnickiego, prof. UW, zatytułowany „Przemiany w Europie Środkowo-Wschodniej. Determinanty i ograniczenia”. Podczas dziewięćdziesięciominutowego wystąpienia prelegent przedstawił stan badań nad przekształceniami ustrojowymi w państwach Europy Środkowo-Wschodniej. Swój wykład rozpoczął od próby zdefiniowania tytułowego regionu, przywołując szereg różnych koncepcji dotyczących terytorialnego zasięgu Europy Środkowo-Wschodniej (np. jedno ze stanowisk utożsamia Europę Środkowo-Wschodnią z tzw. „regionem ABC”, czyli obszarem leżącym pomiędzy trzema morzami - Adriatykiem, Bałtykiem i Morzem Czarnym). Następnie prof. Wojnicki zwrócił uwagę na złożony i wielokierunkowy charakter przemian w Europie Środkowo-Wschodniej. Po pierwsze, przeobrażenia te objęły różne płaszczyzny życia społecznego, m.in. prawo, politykę i gospodarkę, a po drugie, ich tempo i kierunek kształtowały się odmiennie w poszczególnych państwach regionu. To powoduje, że trudno zrozumieć i nazwać procesy, które zachodziły w Europie po zakończeniu zimnej wojny. Nie dziwi zatem fakt, że w literaturze przedmiotu występuje znaczne zróżnico- 
wanie pojęć określających przemiany w regionie środkowo-wschodnioeuropejskim (np. tranzycja, transformacja, marketyzacja czy konsolidacja demokracji). Co istotne, za każdym z tych pojęć kryją się odmienne założenia i stanowiska co do charakteru przeobrażeń. Dotyczy to zarówno zdefiniowania stanu wyjściowego (początkowego), jak również określenia istoty przemian oraz ich punktu docelowego. Czym innym jest np. „prosta” tranzycja, czyli przejście od systemu niedemokratycznego ku demokracji według modelu linearnego, a czym innym transformacja, jako proces nieokreślony, którego rezultaty są nieznane. Co więcej, w literaturze przedmiotu nie ma nawet zgody w kwestii tak fundamentalnej jak zakres czasowy przemian. Wątpliwości badaczy budzi nie tylko określenie cezury końcowej - trudno bowiem bezspornie wskazać jakiś punkt zwrotny bądź te wydarzenia, które wieńczą proces przekształceń - ale dotyczy to nawet momentu początkowego, inicjującego proces przemian. Dla większości autorów tym momentem były wydarzenia 1989 r., określane jako Jesień Ludów; inni wskazują jednak na wydarzenia wcześniejsze, np. ogłoszenie polityki Pierestrojki w ZSRR w 1985 r., bądź strajki w Polsce i na Węgrzech w 1988 r. Różnica zdań dotyczy także określenia miejsca, gdzie przemiany zostały zapoczątkowane. Część badaczy twierdzi, że rozpoczęły się one w Polsce i wywołały efekt lawiny (domina) w pozostałych państwach regionu. Inni wskazują na równoległość przemian w Polsce i na Węgrzech.

Wiele miejsca w swoim wystąpieniu prof. Wojnicki poświęcił na typologię przemian w Europie Środkowo-Wschodniej. W tym kontekście prelegent wyróżnił i scharakteryzował pięć modeli transformacji: 1) historyczny kompromis (Polska, Węgry); 2) upadek i kapitulacja (NRD, Czechosłowacja); 3) kontrolowane otwarcie (Bułgaria, Rumunia); 4) transformacja przez zjednoczenie (RFN i NRD); 5) rozpad państwa federalnego (Jugosławia, ZSRR). Wśród wielu innych wątków, które zostały poruszone w trakcie wykładu, prof. Wojnicki odwołał się także do rozmaitych autorskich koncepcji dotyczących przemian ustrojowych, m.in. do słynnej tezy Francisa Fukuyamy o „końcu historii”, a także do koncepcji „trzeciej fali demokratyzacji” Samuela Huntingtona.

Po wykładzie prof. Wojnickiego kolejnym punktem konferencji była dyskusja nad wystąpieniem, którą moderował prof. dr hab. Andrzej Antoszewski. Uczestnicy dyskusji spierali się m.in. w kwestii przebiegu granic Europy 
Środkowo-Wschodniej oraz przydatności metody komparatystycznej w badaniach państw tego regionu. Wielu dyskutantów podkreślało znaczne zróżnicowanie państw postkomunistycznych, utrudniające dokonywanie jakichkolwiek porównań i generalizacji. Z drugiej strony próbowano znaleźć wspólny mianownik dla tego regionu, wskazując np. na podobne doświadczenia związane z przejściem od gospodarki planowej do modelu rynkowego (tak prof. Katarzyna Sobolewska-Myślik z Uniwersytetu Pedagogicznego w Krakowie). Kilkoro uczestników dyskusji wyraziło pewne nieusatysfakcjonowanie z powodu nieuwzględnienia bądź marginalnego potraktowania w wystąpieniu prof. Wojnickiego problematyki państw bałtyckich. Inni natomiast podkreślali złożoność i długotrwałość procesów transformacji; prof. dr hab. Klaus Ziemer z Uniwersytetu Kardynała Stefana Wyszyńskiego w Warszawie przywołał opinię Ralfa Dahrendorfa, który stwierdził, że potrzeba sześciu miesięcy, aby zmienić ustrój konstytucyjny, sześciu lat, by zmienić system gospodarczy i sześćdziesięciu lat, aby dokonała się zmiana w społeczeństwie (zmiana mentalności).

Po zakończeniu dyskusji nad wystąpieniem prof. Wojnickiego uczestnicy zjazdu spotkali się na uroczystej kolacji.

Drugiego dnia konferencji obrady toczyły się według podobnego schematu co wcześniej - najpierw półtoragodzinny wykład wprowadzający, a następnie dyskusja na temat wystąpienia. Przedmiotem rozważań uczyniono tym razem fenomen autorytaryzmu. Wybór tej problematyki należy uznać za trafny, ponieważ na poprzednich spotkaniach badaczy systemów politycznych - w Mądralinie, Trzebnicy, Ostromecku i Wiśle - dyskusje koncentrowały się przede wszystkim wokół reżimu demokratycznego. Za wyborem tematu autorytaryzmu przemawiają również przesłanki ściśle obiektywne trzeba bowiem pamiętać, że gros państw na świecie stanowią reżimy niedemokratyczne, w których zamieszkuje większość światowej populacji (tak wynika chociażby ze Wskaźnika demokracji - indeksu opracowywanego dla tygodnika „The Economist”). Reżimy te funkcjonują w bezpośrednim sąsiedztwie Unii Europejskiej (państwa poradzieckie, kraje arabskie), ale kryzys demokracji i wzrost tendencji autorytarnych staje się także coraz bardziej widoczny w samej Europie.

Wprowadzenie do dyskusji na temat autorytaryzmu wygłosił prof. dr hab. Andrzej Chodubski z Uniwersytetu Gdańskiego. W wielowątkowym i eru- 
dycyjnym wykładzie zatytułowanym „Autorytaryzm w przestrzeni współczesnych systemów politycznych" prelegent podjął próbę charakterystyki reżimu autorytarnego. Jest to o tyle trudne, że nie ma jednego autorytaryzmu, ponieważ zjawisko to zmieniało się w czasie i przestrzeni. Ponadto brakuje opracowań naukowych tego fenomenu (w literaturze polskiej pewne ustalenia terminologiczne i typologiczne poczynił dr hab. Wojciech Sokół z Uniwersytetu Marii Curie-Skłodowskiej w Lublinie). Mimo tych trudności prelegent zdołał zidentyfikować szereg cech właściwych dla reżimu autorytarnego. Przede wszystkim wskazał na szczególną rolę jednostki autorytarnej, będącej centralną postacią w systemie politycznym, bez której trudno w ogóle mówić o istnieniu autorytaryzmu. Jej podporządkowane są poszczególne instytucje polityczne (parlament, rząd, sądy) oraz siły zbrojne. Jednostka taka, zajmując nadrzędną pozycję w systemie władzy, znajduje się poza jakąkolwiek kontrolą polityczną i nie podlega typowym dla reżimu demokratycznego procedurom egzekwowania odpowiedzialności. Rola parlamentu w autorytaryzmie jest ograniczona (legislatywa przypomina „najdroższy chór świata"), pełni funkcję pewnej dekoracji konstytucyjnej, stwarza pozory funkcjonującej demokracji. Wyraźną przewagę nad ciałem ustawodawczym uzyskuje egzekutywa, znajdująca się wszak pod nadzorem jednostki autorytarnej. W płaszczyźnie ideologicznej autorytaryzm zwraca się przeciwko liberalizmowi, indywidualizmowi, egalitaryzmowi i pluralizmowi. Głosi prymat państwa nad społeczeństwem, kwestionuje ideę wolnych i demokratycznych wyborów, odrzuca instytucję opozycji politycznej, neguje sens istnienia partii politycznych i systemu partyjnego (jednostka autorytarna stoi na czele lub patronuje partii władzy). Profesor Chodubski zwrócił jeszcze uwagę na szereg innych elementów charakterystycznych dla autorytaryzmu.

Po zakończeniu wykładu rozpoczęła się godzinna dyskusja. Jej moderatorem była prof. dr hab. Alicja Stępień-Kuczyńska z Uniwersytetu Łódzkiego. Uczestnicy dyskusji z uznaniem odnieśli się do wystąpienia prof. Chodubskiego, podkreślając wagę i aktualność poruszanej problematyki. Jeszcze raz zwrócono uwagę na potrzebę prowadzenia badań nad autorytaryzmem i wypełnienia luki, jaka istnieje w literaturze przedmiotu. Dr hab. Robert Alberski z Uniwersytetu Wrocławskiego zauważył, że od momentu ukazania się klasycznych prac Juana Linza poświęconych autorytaryzmowi poczy- 
niono niewiele nowych ustaleń w tym obszarze. Z opracowań polskich podejmujących tę problematykę odnotowano publikacje prof. dra hab. Marka Bankowicza z Uniwersytetu Jagiellońskiego.

Na zakończenie konferencji głos zabrał przewodniczący Komitetu Organizacyjnego - dr hab. Andrzej Kubka, prof. UG. - który podziękował wszystkim obecnym za udział. Uczestnicy konferencji dowiedzieli się o miejscu i dacie kolejnego zjazdu badaczy systemów politycznych. Szósty ogólnopolski zjazd katedr i zakładów systemów politycznych odbędzie się w Kazimierzu Dolnym w dniach 22-23 maja 2017 r. i będzie poświęcony problematyce rozliczalności w systemach politycznych. Organizatorem wydarzenia będzie Zakład Systemów Politycznych Uniwersytetu Marii Curie-Skłodowskiej w Lublinie. Przekazano także, że rolę gospodarza kolejnego (siódmego) zjazdu badaczy systemów politycznych będzie pełnił Uniwersytet Łódzki.

Michał Wallner Uniwersytet Marii Curie-Skłodowskiej 